\author{
N.Ashirbayev, Zh.Ashirbayeva, T.Sultanbek, M.Shomanbayeva \\ M.O.Auezov South Kazakhstan State University, Shymkent, Kazakhstan \\ (E-mail: ank_56@mail.ru)
}

\title{
Waves of elastic stresses in the doubly-connected domain
}

\begin{abstract}
In this paper, we consider a nonstationary mixed problem of impact of a rigid plate on the face surface of the base body containing inside itself a central foreign inclusion. Formulated in terms of stresses and velocities of displacements, the mixed problem is modeled numerically by means of an explicit difference scheme of a through count, based on the method of the spatial characteristics. The results of a change in the wave fields in a doubly connected domain are presented in the form of graphs. The analysis of numerical information made it possible to investigate the dynamic effects of stress concentration in the neighborhood of the contact of a doubly-connected domain, as well as near the corner points of a foreign inclusion.
\end{abstract}

Keywords: elastic, wave process, stress, speed, foreign inclusion, numerical solution, boundary condition.

The leading factor determining the efficiency of modern engineering structures is their layered heterogeneous structure. In connection with this, the study of dynamic wave processes in deformable multiply connected media in order to determine the nature of possible damage has, in addition to purely scientific interest, an important applied value. In general, the number of works devoted to dynamic problems, taking into account a number of weakening factors, is very small, they do not consider all aspects of their performance under the conditions of nonstationary external loads [1-4]. However, the interest in these problems, primarily due to the importance of solving complex practical problems, is great, and further improvement of numerical methods in various modifications with the use of increasingly sophisticated computer technology should lead to a substantial development of this direction.

Statement of the problem. A strip with a rectangular cross-section of finite sizes, consisting of a main body and a central rectangular foreign inclusion, occupies a region in the Cartesian coordinate system $x_{1} 0 x_{2}$ (Fig. 1). The physical and mechanical properties of the body $(i=1)$ and the foreign inclusion $(i=2)$ are characterized by the density of the material $\rho_{i}$, the velocities of the longitudinal and transverse elastic waves $a_{i}, b_{i}$.

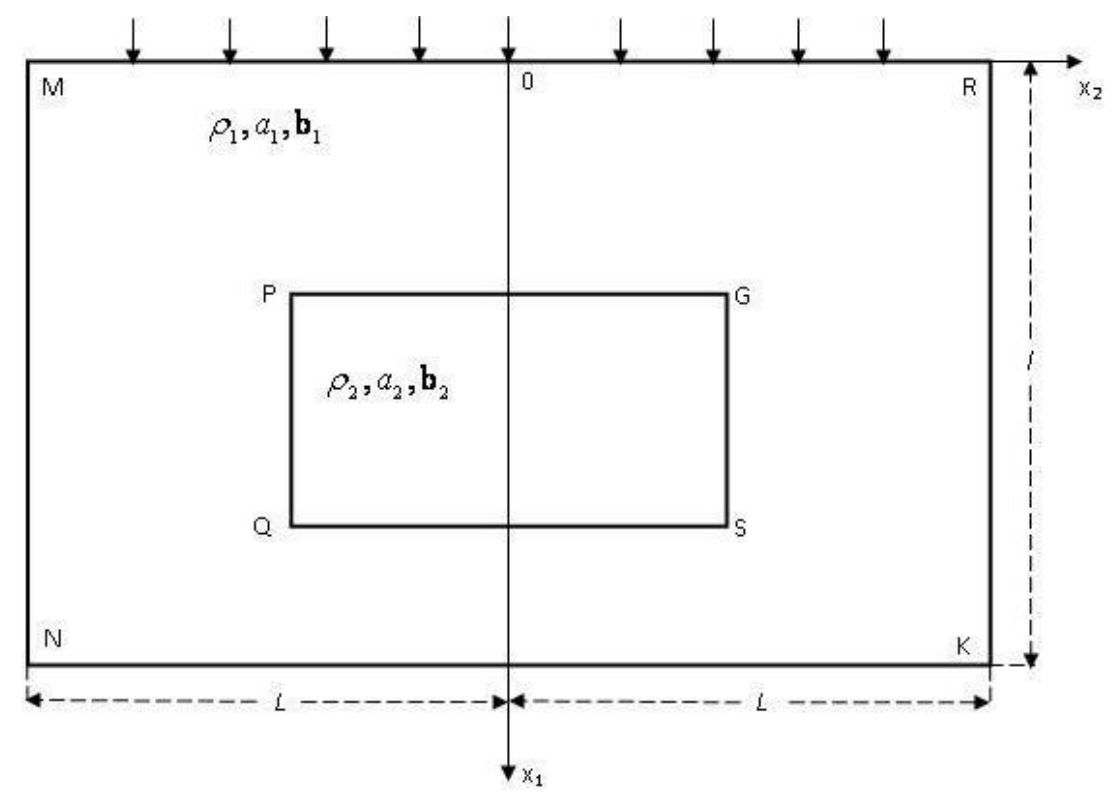

Figure 1. Study area 
At the initial time $t=0$, an absolute rigid body with a displacement velocity $v_{1}^{(1)}=f(t)$ and $v_{2}^{(1)}=0$ strikes the outer boundary $x_{1}=0,\left|x_{2}\right| \leq l$ of the principal body in a static equilibrium state of the doubly-connected domain. The problem is to determine within the doubly-connected domain $0 \leq x_{1} \leq \ell,\left|x_{2}\right| \leq L$ the stress and displacement velocity fields caused by fronts of incident and repeatedly reflected, refractive and diffracted elastic waves at time moments $t>0$.

A mathematical model of the wave process at interior points of a doubly-connected domain is a linear system of dynamical equations of hyperbolic type containing as unknowns the dimensionless stresses $p^{(i)}, q^{(i)}, \tau^{(i)}$, speed of displacements $v_{1}, v_{2}[5]$ :

$$
\begin{gathered}
\rho_{(i)} \cdot v_{1, t}^{(i)}-p_{, 1}^{(i)}-q_{, 1}^{(i)}-\tau_{, 2}^{(i)}=0 ; \quad \rho_{(i)} \cdot v_{2, t}^{(i)}-p_{, 2}^{(i)}+q_{, 2}^{(i)}-\tau_{, 1}^{(i)}=0 \\
\frac{1}{\rho_{i} \cdot\left(a_{i}^{2}-b_{i}^{2}\right)} \cdot p_{, t}^{(i)}-v_{1,1}^{(i)}-v_{2,2}^{(i)}=0 \\
\frac{1}{\rho_{i} \cdot b_{i}^{2}} \cdot q_{, t}^{(i)}-v_{1,1}^{(i)}+v_{2,2}^{(i)}=0 \\
\frac{1}{\rho_{i} \cdot b_{i}^{2}} \cdot \tau_{, t}^{(i)}-v_{1,2}^{(i)}-v_{2,1}^{(i)}=0
\end{gathered}
$$

where

$$
a_{i}=\frac{a_{i}^{0}}{a_{m}^{0}}, \quad b_{i}=\frac{b_{i}^{0}}{a_{m}^{0}}, \quad \rho_{i}=\frac{\rho_{i}^{0}}{\rho_{m}^{0}}, \quad(i=1,2) .
$$

Here $v_{1}^{(i)}\left(x_{1}, x_{2}, t\right), \quad v_{2}^{(i)}\left(x_{1}, x_{2}, t\right)$ are the components of the displacement velocity vector in the direction of the coordinate axes $x_{1}$ and $x_{2}$. The transition to dimensionless variables was carried out according to the formulas [5]:

$$
\begin{gathered}
t=\frac{t^{0} \cdot a_{m}^{0}}{b^{0}}, \quad x_{k}=\frac{x_{k}^{0}}{b^{0}}, \quad v_{k}=\frac{v_{k}^{0}}{a_{m}^{0}} \quad(k=1,2) ; \\
p=\frac{\sigma_{11}^{0}+\sigma_{22}^{0}}{2 \cdot \rho_{m}^{0} \cdot a_{m}^{0^{2}}}, \quad q=\frac{\sigma_{11}^{0}-\sigma_{22}^{0}}{2 \cdot \rho_{m}^{0} \cdot a_{m}^{0^{2}}}, \quad \tau=\frac{\sigma_{12}^{0}}{\rho_{m}^{0} \cdot a_{m}^{0^{2}}} .
\end{gathered}
$$

The upper index $\ll 0 »$ is given to the dimensional values; $b^{0}$ is the characteristic size; the index $i(i=1,2)$ corresponds to the main body if $i=1$, and to a foreign inclusion if $i=2$; the index $m$ refers to a material in which the velocity of propagation of longitudinal elastic waves is a maximum $\left(a_{m}^{0}=\max _{i} a_{i}^{0}\right) ; \quad \sigma_{11}^{0}, \sigma_{22}^{0}, \sigma_{12}^{0}$ are the components of the stress tensor. We assume that the velocity of propagation of longitudinal elastic waves in the main body is the greatest.

To determine the wave field in a doubly-connected domain caused by a dynamic action on the face frontier $x_{1}=0,\left|x_{2}\right| \leq L$, of the main body, it is necessary to integrate for $t>0$ the hyperbolic system of differential equations (1) with zero initial data

$$
v_{1}^{(i)}=v_{2}^{(i)}=p^{(i)}=q^{(i)}=\tau^{(i)}=0 \quad(i=1,2)
$$

and the following boundary conditions for $t \geq 0$ :

$$
\begin{gathered}
v_{1}^{(1)}=f(t), \quad v_{2}^{(1)}=0 \quad \text { for } \quad x_{1}=0, \quad\left|x_{2}\right| \leq L ; \\
p^{(1)}-q^{(1)}=0, \quad \tau^{(1)}=0 \quad \text { for } \quad x_{2}=L, \quad 0 \leq x_{1} \mid \leq \ell ; \\
v_{1}^{(1)}=0, \quad v_{2}^{(1)}=0 \quad \text { for } \quad x_{1}=\ell, \quad\left|x_{2}\right| \leq L, \\
p^{(1)}+q^{(1)}=p^{(2)}+q^{(2)}, \quad \tau^{(1)}=\tau^{(2)}, \quad v_{1}^{(1)}=v_{1}^{(2)}, \quad v_{2}^{(1)}=v_{2}^{(2)}
\end{gathered}
$$

on contact borders $P G$ and $Q S$ and

$$
p^{(1)}-q^{(1)}=p^{(2)}-q^{(2)}, \quad \tau^{(1)}=\tau^{(2)}, \quad v_{1}^{(1)}=v_{1}^{(2)}, \quad v_{2}^{(1)}=v_{2}^{(2)}
$$

on contact borders $P Q$ and $G S$. 
Here $f(t)$ is a given function that monotonically increases to the maximum value $f\left(t_{0}\right)$, and then decreases monotonically. The zero initial conditions (3) mean that a doubly connected region is at rest up to the time $t \leq 0$. The boundary condition (4) corresponds to the specification of the normal component of the particles' velocity and to the absence of a tangential component of the particles' velocity on the boundary $x_{1}=0,\left|x_{2}\right| \leq L$ of the base body for all instants of time. The boundary conditions (5) mean that the lateral surfaces $\left|x_{2}\right|=L$ of the base body are free from stresses for all instants of time. The boundary condition (6) corresponds to the condition of rigid fixation of the points of the surface $\left|x_{2}\right|=\ell$ of the base body.

The boundary conditions (7) and (8) at the contact boundaries of the main body and the foreign inclusion correspond to the usual conditions of rigid contact. The conditions connecting the stresses at the contact boundaries are the formulation of Newton's third law, and the remaining ones that connect the particle velocities ensure the continuity of the doubly-connected domain.

At the accepted loading in the body it is appeared a complex process of propagation of longitudinal waves in the directions of the axes $x_{1}, x_{2}$ and propagation of transverse waves. After a while (depending on the size and speed of propagation of disturbances) they begin to interfere. To determine the stresses and velocities of particles in a doubly connected region, it is necessary to integrate the hyperbolic system of differential equations (1) for given zero and boundary conditions (3)-(8).

The solution of the system of equations (1) for initial (3) and boundary (4)-(8) conditions is found by the method of spatial characteristics at the nodal points, into which the entire doubly-connected region is divided [6]. The peculiarity of the considered body is that on the contact boundaries of the doubly connected domain, as well as at the inner corner points $(P, G, Q, S)$ of foreign inclusion, the «smoothness» of the functions «usual» for dynamic problems is violated. In general, as we know, there were no methods for solving the tasks with such singularities. In addition to the known relations [6], the calculated relations on the contact boundaries of the doubly-connected domain and also at the internal corner points $(P, G, Q, S)$ of the foreign inclusion are obtained [5].

The developed technique was numerically realized for a rectangular strip $\left(0 \leq x_{1} \leq 14 \cdot h\right),\left|x_{2}\right| \leq 12 \cdot h$ with central foreign inclusion $\left(4 \cdot h \leq x_{1} \leq 10 \cdot h\right),\left|x_{2}\right| \leq 4 \cdot h$ for hard coupling of dissimilar materials. The material of the main body is steel $\left(i=1, p_{1}^{0}=7.9 \cdot 10^{3} \mathrm{~kg} / \mathrm{m}^{3}, a_{1}^{0}=5817 \mathrm{~m} / \mathrm{sec}, b_{1}^{0}=3109 \mathrm{~m} / \mathrm{sec}\right)$, and the foreign inclusion - copper $\left(i=2, p_{2}^{0}=8.9 \cdot 10^{3} \mathrm{~kg} / \mathrm{m}^{3}, a_{2}^{0}=4557 \mathrm{~m} / \mathrm{sec}, b_{2}^{0}=2131 \mathrm{~m} / \mathrm{s}\right)$. The program, written in the Fortran language, allows us to calculate a sufficiently wide class of dynamic problems describing unsteady wave processes in multiply connected isotropic media. The wavefield parameters were calculated for a band with a central foreign inclusion at the following values of the initial data: $\ell=0.7, L=0.6, h=\triangle x_{1}=\triangle x_{2}=0.05$, $k=\Delta t=0.025, f(t)=t \cdot e^{t}$ for $t \geq 0$ and for $f(t)=0$. The time step $k$ is chosen in accordance with the necessary stability conditions

$$
\left(\frac{k}{h}\right)^{2} \leq \min \left\{\frac{\gamma^{2}}{\gamma^{2}+1}, \frac{\gamma^{2}}{\left(2 \gamma^{2}-1\right)}\right\}
$$

of the explicit finite-difference calculation scheme used. For comparison, the calculation was carried out for a single-connected steel strip without foreign inclusion with the same boundary conditions.

The results of calculations are presented in the form of graphs of the variation of various functions as a function of time at fixed points and the distribution of these same functions wih respect to the coordinate for certain fixed time instants. An analysis of the obtained results reveals certain features of the process of propagation of perturbations in a doubly connected medium. Because of the symmetry of the location of the foreign inclusion and the nature of the loading, the normal stresses $p^{(i)}, q^{(i)}$ and the longitudinal velocity $v_{1}^{(i)}$ are symmetric, and the tangent stress $\tau^{(i)}$ and the transverse velocity $v_{2}^{(i)}$ are antisymmetric with respect to the axis $x_{2}=0$. In this connection, Figures $2-4$ show the results of calculations only for positive values of $x_{2},\left(x_{2} \geq 0\right)$.

The calculated oscillograms of the transverse $v_{2}^{(i)}$ particle velocity in the time interval $t \in[0,100 \cdot k]$ at nine fixed observation points $1\left(x_{1}=2 \cdot h, x_{2}=2 \cdot h\right), 2\left(x_{1}=2 \cdot h, x_{2}=10 \cdot h\right), 3\left(x_{1}=7 \cdot h, x_{2}=2 \cdot h\right)$, $4\left(x_{1}=7 \cdot h, x_{2}=10 \cdot h\right), 5\left(x_{1}=12 \cdot h, x_{2}=2 \cdot h\right), 6\left(x_{1}=12 \cdot h, x_{2}=10 \cdot h\right), 7\left(x_{1}=0, x_{2}=0\right)$, $8\left(x_{1}=7 \cdot h, x_{2}=4 \cdot h\right), 9\left(x_{1}=4 \cdot h, x_{2}=2 \cdot h\right)$ are represented by the curves in Figure 2 . The solid curves with round points indicate the velocities displacements arising in a simply connected strip without foreign inclusion with the same boundary conditions. The appearance time of the transverse component of the velocity $v_{2}^{(i)}$ and its magnitude are completely determined by the transverse-wave fronts. The transverse component of the velocity $v_{2}^{(i)}$ at point 1 is small. Therefore, at the point under consideration, near the symmetry axis $x_{2}=0$, we can assume that the condition for a quasi-one-dimensional motion is satisfied. 
The displacement speed $v_{2}^{(i)}$, generated by the diffraction waves from the angle $R\left(x_{1}=0, x_{2}=0.6\right)$, appears at point 2 before $(t \approx 5 \cdot k)$ than at the point $1(t \approx 24 \cdot k)$. At $t \approx 13 \cdot k$ point 4 is already covered by additional transverse motion due to arrival of diffracted waves emanating from the angle $R$ and from the free surface $R K\left(x_{2}=0.6\right)$ of the base body. From the form of the velocity of displacement $v_{2}^{(i)}$ at the point $3(t \approx 15 \cdot k)$ (for the simply connected (curve $3-\bullet--$ ) and doubly connected (curve 3 - -) regions), the effect of the diffraction of the angle $G$ of a foreign inclusion is well traced. The appearance of the transverse velocity $v_{2}^{(i)}$ at point 5 for $(t \approx 23 \cdot k)$ is due to the diffraction of transverse waves from the angle $S$ of foreign inclusion.

At a distance of $10 \cdot h$ from the axis $x_{2}=0$ (points $2,4,6$ ), the impact of the diffraction fronts is more significant than their influence at points 1,3,5 located near the axis of symmetry. The motion polarized in the transverse direction has less propagation velocity than the velocity of the displacement of the longitudinal wave. The diagrams for the transverse velocity of displacements $v_{2}^{(i)}$ are characterized by the presence of a set of local extrema, which is caused by the interaction of multiply reflected, refracted and diffracted waves. And this, in turn, determines the pulsating nature of the movement in the transverse direction.

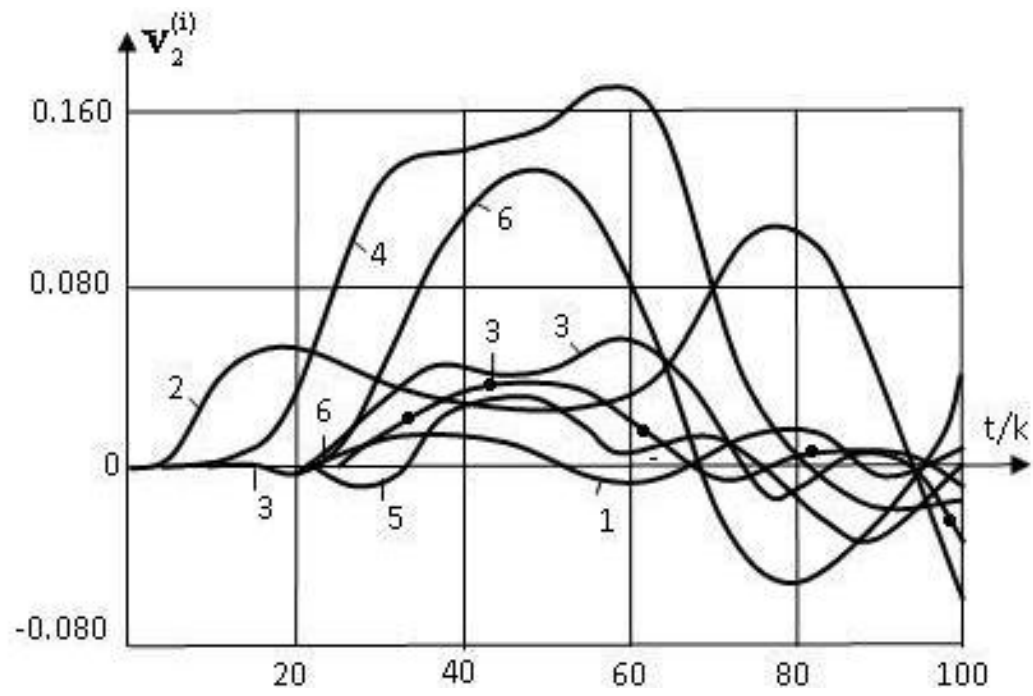

Figure 2. Oscillogram of transverse velocities $v_{2}^{(i)}$ of particles at nine fixed observation points

Comparison of kinematic parameters of motion at six points of a doubly connected medium with corresponding values in a simply connected medium shows that the influence of the material of foreign inclusion with acoustic stiffness, which is twice less than the stiffness of the material of the main body, significantly affects the magnitude and character of the change in the velocity vector $v_{2}^{(i)}$ of particles in time at points $1,3,5$. As well as the presence of foreign inclusion significantly affects the early appearance of the transverse component of the displacement velocity $v_{2}^{(i)}$ at points 3 and 5 .

Figure 3 shows the isolines of normal stresses $p^{(i)}+q^{(i)}=$ const in the plane $x_{1} / h \cdot x_{2} / h$ for the time $(t \approx 50 \cdot k)$. Sequential action of plane wave fronts, their interaction with reflected, refracted and diffracted waves leads to a dynamic concentration of compressive stresses near the corner points $(G S)$ of foreign inclusion in which they reach local maxima. At this time, a relatively high concentration is formed around the corner point $G$. The degree of stress concentration around the corner points varies with time. The maximum concentration $(t \approx 50 \cdot k)$ is observed near the corner points $R, K$ of the strip in the vicinity of which the stress field has the largest gradients.

In conditions of the existence of internal points with maximum stresses, it becomes important to ensure the compatibility of the deformation of the materials of the foreign inclusion and the main body.

The distribution of the tangential stress $\tau^{(i)}$ in $x_{2} / h$ in the sections $x_{1}=2 \cdot h(1), \quad x_{1}=4 \cdot h(2)$, $x_{1}=7 \cdot h(3), x_{1}=10 \cdot h(4), x_{1}=12 \cdot h(5)$, is shown in Figure 3 for the time moment $(t \approx 50 \cdot k)$. The maximum values of the stresses in sections 1 and 5 arise in the vicinity. 


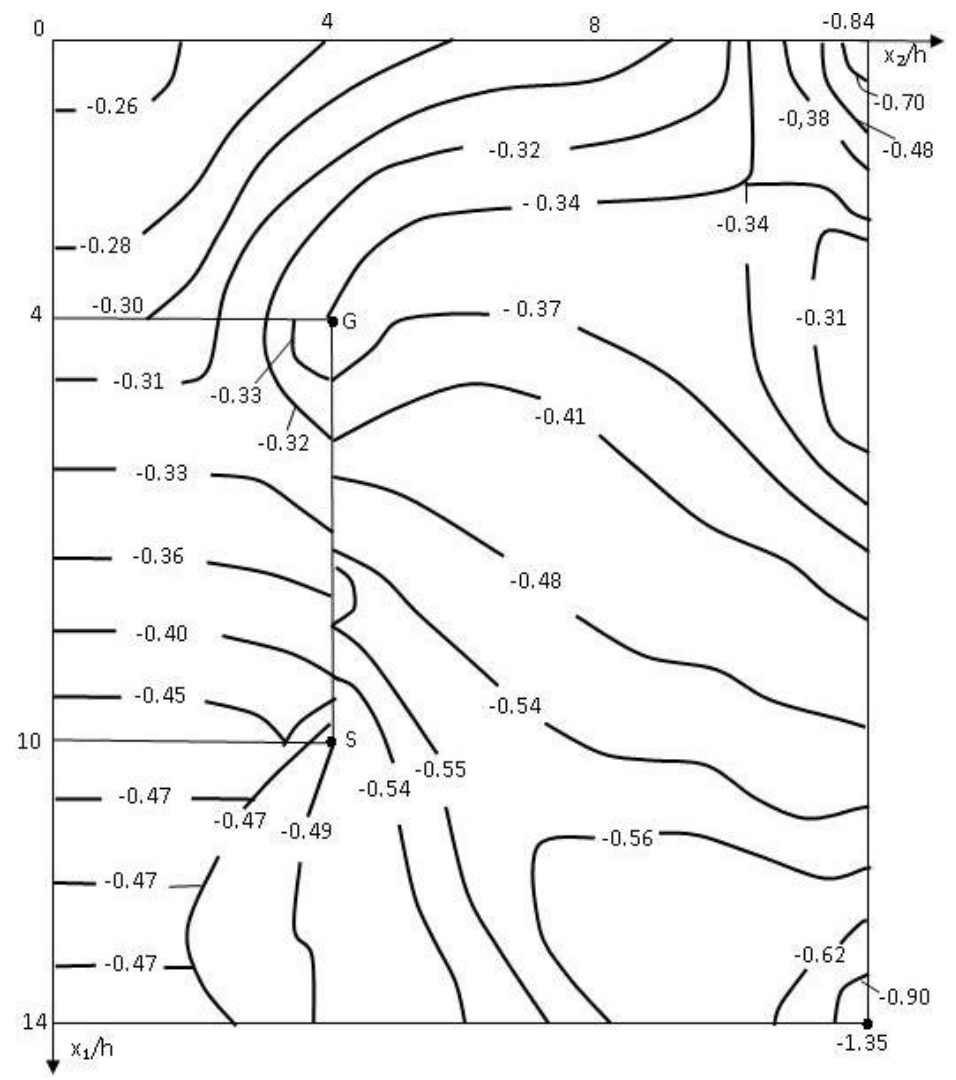

Figure 3. Isolines of normal stresses $p^{(i)}+q^{(i)}=$ const at the time $t=50 \cdot k$

The maximum values of the stresses in sections 1 and 5 arise in the vicinity of free surface $R K$ of the band. In the neighborhood of the corner points $G, S$ of a foreign inclusion located in sections 2, 4, significant changes in the behavior of tangential stresses are noted. The presence of sections of the sharp changes in $\tau^{(i)}$ is due to the piecewise heterogeneity of the material properties and the additional wave diffraction caused by them. At the moment considered, the effect of diffraction waves emanating from the corner points of a foreign inclusion on the nature of the change of the tangent stresses $\tau^{(i)}$ is weaker in the remaining sections along the $x_{2} / h$ axis, but over time it becomes more noticeable (Fig. 4).

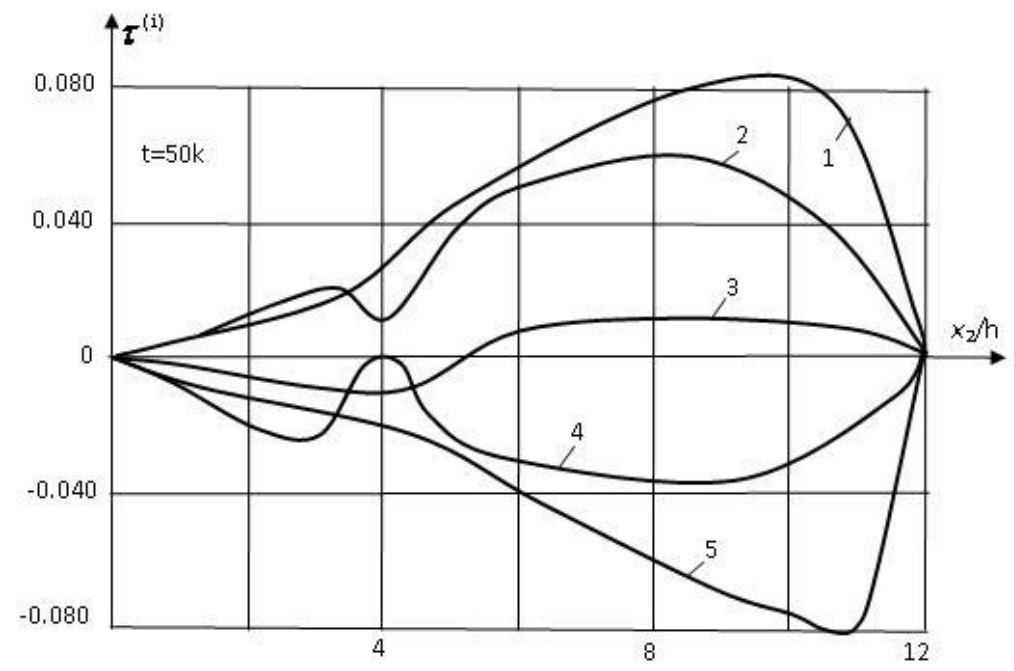

Figure 4. Change of tangent stress $\tau^{(i)}$ with respect to $x_{2} / h$ in cross-sections $x_{1}=2 h(1), x_{1}=4 h(2), x_{1}=7 h(3), x_{1}=10 h(4), x_{1}=12 h(5)$ 
As a result of the studies carried out, it can be concluded that the developed calculation technique for nonstationary dynamic problems with a centrally located foreign inclusion of a rectangular shape quite correctly conveys the main regularities and features of the ongoing wave processes and makes it possible to study the stress-strain states in simply connected and multiply connected media with a complex system of inhomogeneities of the considered types.

\title{
References
}

1 Кукуджанов В.Н. Деформирование, повреждаемость и разрушение сред и материалов с дефектами и со структурами дефектов / В.Н. Кукуджанов // Вестн. Нижегород. ун-та им. Н.И. Лобачевского. - 2011. - № 4(4). 一С. 1557-1558.

2 Alexeeva L.A. Mathematical model of massive dynamics in the neighborhood of disturbance focus: International Conference on Advancements in Mathematical Sciences, AIP Conference Proceedings 1676 / L.A. Alexeeva, B.T. Sarsenov. (American Institute of Physics, Melville, NY, 2015), 020055.

3 Ashirbayev N. Modeling and solving the twodimensional non-stationary problem in an elastic body with a rectangular hole / N.Ashirbayev, Zh.Ashirbayeva, T.Sultanbek, R.Bekmoldayeva // AIP Conference Proceedings. - 2016. - Vol. 1759, 020078, http://dx.doi.org/10.1063/1.4959692.

4 Ashirbayev N. Features of the Wave Field in a Finite Body with a Noncentral Hole. Functional analysis in interdisciplinary applications: International Conference (FAIA2017), AIP Conference Proceedings 1880 / N.Ashirbayev, Zh.Ashirbayeva, M.Shomanbayeva (American Institute of Physics, Melville, NY, 2017), 060013 (2017); http://doi.org/10.1063/1.5000667.

5 Аширбаев Н.К. Расчетные соотношения динамической задачи для прямоугольной области с инородными включениями / Н.К. Аширбаев, Ж.Н. Аширбаева // Вестн. КазНИТУ. — 2017. — № 4(122). - C. 500-506.

6 Clifton R.J. A difference method for plane problems in dynamic elasticity / R.J. Clifton // Quart. Appl. Math. - 1967. - Vol. 25. - No. 1. - P. 97-116.

Н.Әшірбаев, Ж.Әшірбаева, Т.Сұлтанбек, М.Шоманбаева

\section{Екібайламды облыстағы серпімді кернеулік толқындар}

\begin{abstract}
Мақалада орталық ішкі бөлігі басқа бөгде материалмен толтырылған негізгі дененің сыртқы бет жағынан қатты штамппен ұрған кездегі стационар емес аралас есеп қарастырылған. Кернеулер мен жылдамдықтар терминінде қойылған аралас есеп айқын айырымдық схема, атап айтқанда, сандық кеңістіктік сипаттамалар әдісімен шешілген. Екібайламды облыста пайда болатын толқындық өрістің өзгеру процесі графиктер түрінде берілген. Алынған сандық нәтижелерді талдау барысында екібайламды облыстың түйіскен жанасу нүктелері мен бөгде дененің бұрыштық нүктелерінің маңайында кернеулер концентрациясының динамикалық эффектісін зерттеуге мүмкіндік берді.
\end{abstract}

Кілт сөздер: серпімділік, толқындық үрдіс, кернеулік, бөгде дені, сандық шешім.

\section{Н.Аширбаев, Ж.Аширбаева, Т.Султанбек, М.Шоманбаева}

\section{Волны упругих напряжений в двухсвязной области}

В работе рассмотрена нестационарная смешанная задача об ударе жесткого штампа по лицевой поверхности основного тела, содержащего внутри себя центральное инородное включение. Сформулированная в терминах напряжений и скоростей перемещений смешанная задача моделируется численно с помощью явной разностной схемы сквозного счета, основанной на методе пространственных характеристик. В виде графиков представлены результаты изменения волновых полей в двухсвязной области. Анализ числовой информации позволил исследовать динамические эффекты концентрации 
напряжений в окрестности контакта двухсвязной области, а также вблизи угловых точек инородного включения.

Ключевые слова: упругость, волновой процесс, напряжение, скорость, инородное включение, численное решение, граничное условие.

\section{References}

1 Kukudzhanov, V.N. (2011). Deformirovanie, povrezhdaemost i razrushenie sred i materialov s defektami i so strukturami defektov [The deformation, defect and destruction of materials with defects and defects with structures]. Vestnik Nizhehorodskoho universiteta imeni N.I. Lobachevskoho - Vestnik of Lobachevsky University of Nizhni Novgorod, No. 4(4), 1557-1558 [in Russian].

2 Alexeeva, L.A., \& Sarsenov, B.T. (2015). Mathematical model of massive dynamics in the neighborhood of disturbance focus, in International Conference on Advancements in Mathematical Sciences, AIP Conference Proceedings 1676 (American Institute of Physics, Melville, NY), 020055.

3 Ashirbayev, N., Ashirbayeva, Zh., Sultanbek, T., \& Bekmoldayeva, R. (2016). Modeling and solving the two-dimensional non-stationary problem in an elastic body with a rectangular hole. AIP Conference Proceedings, 1759, 020078. Retrieved from http://dx.doi.org/10.1063/1.4959692.

4 Ashirbayev, N., Ashirbayeva, Zh., \& Shomanbayeva, M. (2017). Features of the Wave Field in a Finite Body with a Noncentral Hole. Proceedings from Functional analysis in interdisciplinary applications: International Conference (FAIA2017), AIP Conference Proceedings 1880, (American Institute of Physics, Melville, NY), 060013. Retrieved from http://doi.org/10.1063/1.5000667.

5 Ashirbayev, N.K., \& Ashirbayeva, Zh.N. (2017). Raschetnye sootnosheniia dinamicheskoi zadachi dlia priamouholnoi oblasti s inorodnymi vkliucheniiami [Calculation relations of the dynamic problem for a rectangular domain with foreign inclusions]. Vestnik KazNITU - Vestnik of KazNRTU, 4(122), 500-506 [in Russian].

6 Clifton, R.J. (1967). A difference method for plane problems in dynamic elasticity. Quart. Appl. Math., 25, 1, 97-116. 